\section{Å undervise er å lære to ganger}

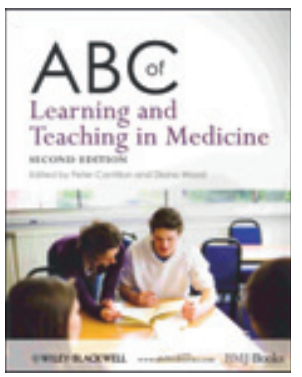

Peter Cantillon, Diana Wood, red. $A B C$ of learning and teaching in medicine

2. utg. $86 \mathrm{~s}$, tab, ill. Chichester: WileyBlackwell, 2010. Pris GBP 20

ISBN 978-1-4051-8597-4

Sitatet i overskriften tilskrives den franske moralisten og essayisten Joseph Joubert (1754-1824). Da jeg var student, lærte professor Sverre Halvorsen oss den norske varianten: «Jeg lærer så lenge jeg har elever.» Begge sitatene kunne stått som tittel på boken som kom ut første gang i 2003, og som nå foreligger i andre utgave.

Boken inngår i en serie $\mathrm{ABC}$-bøker fra BMJ Books. Den er kortfattet og lettlest, men samtidig omfattende nok for alle som skal lære selv (studenten), lære bort (underviseren) eller fremme og lette læringen (fasilitatoren). Tre forhold gjør den særlig verdt å anbefale. For det første bidrar mer enn 20 erfarne fagpersoner på en forbilledlig ensartet måte. De 17 kapitlene har én-to forfattere, et omfang på fire-seks sider og følger nøyaktig samme mal. Starten er en ramme med et innledende overblikk. Så følger en velredigert tekst supplert av faktabokser, illustrasjoner, praktiske eksempler og tips, i tillegg til et og annet velplassert sitat. Teksten har følgende tre kjennetegn: stikkord til tema, stegvis tilnærming og bruk av akronymer. Man avslutter kapitlet med anbefalt litteratur og et fåtall referanser.

For det andre er temaene sentrale. Her er det du trenger å vite, mer eller mindre samlet på et brett. Det er utforming av undervisningstilbud og -materiell, kollektiv læring, fordeler og utfordringer ved undervisning i små og store grupper, og hvordan undervisningen kan tilpasses omgivelsene, særlig til klinisk arbeid. Som eksempel på en dysfunksjonell gruppe, er bildet fra teselskapet i Alice $i$ Eventyrland glitrende. Mot slutten er det to spennende kapitler om hvordan man kan lære profesjonalitet, og hvordan man kan møte studenter som opplever vanskeligheter i studiet.

Gjennom kapitlene går det en rød tråd som kan oppsummeres med tre ord: læring, vurdering og bruk. Boken inneholder bl.a. tre meget leseverdige kapitler om ulike former for evaluering og et kapittel om bruken av tilbakemelding.

Det tredje forholdet ved denne boken er at vi ikke har noe annet sted å gå for å finne maken. Etter 35 år som medisinsk underviser er jeg ute av stand til å navngi fem personer i Norge som passer til betegnelsen medisinsk pedagog. Faget har selvsagt et stort antall utmerkede lærere, men størsteparten er i første rekke fremragende i kraft av talent, interesse, faglig kompetanse og integritet. Og er det noe vi har lært av de store, årlige medisinske utdanningskonferansene, så er det at inspirasjonen i første rekke har kommet fra Skottland og England (1). Visste du forresten at det utgis en egen skriftserie som heter Best Evidenced Medical Education (BEME)?

Siden 1990 har alle de fire medisinske fakultetene i Norge enten foretatt omfattende endringer i sin studieplan og/eller revidert den. Det er ikke lett å vite om og i hvilken grad kunnskap og prinsipper som er nedfelt i denne boken, har påvirket disse endringene. Sikkert er det $\mathrm{i}$ hvert fall at jeg trygt kan anbefale den til alle som på en eller annen måte deltar i utdanningen av norske medisinere. Helst burde fakulteter med respekt for seg selv skaffe den til alle sine lærere. Og det er nesten slik at den burde ligge ved brevet som ønsker hver ny student velkommen til oppstart av medisinstudiet.

\section{Geir W. Jacobsen}

Institutt for samfunnsmedisin

Norges teknisk-naturvitenskapelige universitet

Litteratur

1. Jacobsen G. Størst innen medisinsk utdanning. Tidsskr Nor Legeforen 2008 128: $1850-1$.

\section{Lettfattelig bok for nybegynnere}

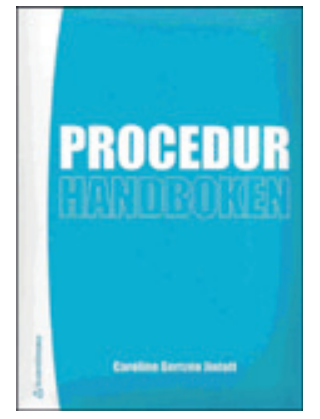

\section{Caroline Gertzén Jintoft \\ Procedurhandboken}

Praktiska moment för diagnos och behandling. $171 \mathrm{~s}$, tab, ill.

Lund: Studentlitteratur, 2010. Pris SEK 234

ISBN 978-91-44-05018-8

Denne boken er skrevet av en relativt nyutdannet svensk lege, som i sitt daglige virke savnet en lett tilgjengelig bok som beskriver vanlige medisinske prosedyrer. Dette savnet førte til at hun skrev boken selv. Hun starter med å beskrive hvordan man desinfiserer hud før hun beskriver forskjellige typer lokalanestesi. Deretter følger kapitler om luftveier/lunger, bl.a. beskrivelse av maskeventilering, intubering, innleggelse av thoraxdren og pleuratapping. I neste kapittel tar forfatteren for seg huden og forskjellige biopsityper og hvordan man f.eks. fjerner inngrodde negler. Forfatteren går så over til å beskrive hvordan man gjør vene- og arteriepunksjoner. Før hun beskriver reponering og gipsing, forklarer hun hvordan man legger forskjellige typer nerveblokader. Punksjon av de store leddene omtaler Jintoft på en lettfattelig måte før hun redegjør for hvordan man gjør en beinmargspunksjon.

I siste del belyser forfatteren noen hasteprosedyrer innen oftamologien og øre-nese-hals-faget, f.eks. fjerning av fremmedlegemer fra øynene og nesen.

Forfatteren går igjennom gastroenterologiske prosedyrer som ascitestapping, nedlegging av ventrikkelsonde og rektoskopi. Deretter utdyper hun hvordan man gjør urinkateterisering, hvordan man tar prøver med tanke på kjønnssykdommer, og hvordan man lager cervixutstryk. Det siste kapitlet omhandler infeksjoner, der man går gjennom praktiske tips for prøvetakning.

Siden målgruppen primært er snart ferdige leger, turnusleger, ferske leger i sykehus og i allmennmedisin, fikk jeg fem legestudenter i femte studieår til å lese boken.

Deres kommentarer var at boken er lettlest, tross at den er skrevet på svensk, den er lagt opp på en didaktisk god måte med enkle og lettfattelige illustrasjoner, og den egner seg ypperlig som et supplement til å lære av mer erfarne kolleger. En av studentene sydde et kutt på en finger og leste boken etterpå. «Hadde jeg lest boken på forhånd, hadde det gått enda bedre med forberedelsene og selve syingen,» sa han.

Det jeg savner, er et kapittel om akutte brystsmerter, der man kunne ha tatt for seg symptomer på akutt koronarsyndrom og enkle kjøreregler når det gjelder EKG-tolkning.

Enda mer aktuell for norske forhold ville en oversettelse bli. Ord som tumskena, KAD og syfte er ikke ord som alle nordmenn forstår, men siden boken er så godt illustrert, skjønner vi ut fra sammenhengen hva ordene betyr.

Referansene er relativt få og oversiktlige. På andre og nest siste side er det en oversikt over akutt hjerteredning og handlingsplan for behandling av akutt luftveisobstruksjon.

Jeg anbefaler at studenter kjøper boken i siste del av medisinstudiet. Mottaksavdelinger og legekontorer, særlig der man har turnusleger, bør ha den.

Den er imidlertid litt for stor til å passe i en normal norsk legefrakklomme.

\section{Øistein Hovde}

Medisinsk avdeling

Sykehuset Innlandet

Gjøvik 